\title{
PERCEPTIONS AND PREVALENCE OF CAVING-SKILLS TRAINING IN THE UNITED STATES AND THE UNITED KINGDOM
}

\author{
Aaron J. Bird ${ }^{1,2 *}$, Melissa Sawa ${ }^{1}$, and Mike Wiles ${ }^{3}$
}

\begin{abstract}
Results are presented of a study of perceptions of caving-skills training. Information in the current study was obtained from questionnaires submitted between May 2011 and February 2012 by recreational cavers, researchers, and others who visit caves for enjoyment, exploration, research, or work. Respondents overwhelmingly support a connection between training and safety during cave visits. In the United States, there is an even split in numbers of people who report having had formal and informal caving-skills training. In the United Kingdom, more respondents report having had informal training than formal. In both the US and UK, experience level is high among respondents, but is not a statistically significant predictor for training type, although large majorities agree training is valuable. Outcomes from this research are used as a basis for discussion of the efficacy of caving-skills training programs in the United States and for discussion of caving-skills training already present in other countries where caving is prevalent, represented here by the United Kingdom.
\end{abstract}

\section{INTRODUCTION}

Many people enter and explore caves for recreation or work activities. While it is currently unknown how many people visit caves in the US for recreation, the National Speleological Society reports its membership at 10,100 (Wm Shrewsbury, NSS President, personal communication, 24 March 2012), which is an indicator of the number of people who are aware of caves and value them. Caves are popular in other parts of the world, as well. In France, it is estimated that approximately 7,500 people are members of the French Federation of Speleology. The UK has approximately 5,750 members of its clubs and organizations (BCA, 2011). Many other countries have national level federations related to cave exploration and cave science, including Spain, Portugal, Italy, Belgium, Austria, Bulgaria, Croatia, Slovenia, Russia, China, and Mexico.

Recreation is a primary reason why people enter caves, but not the only one. There are a significant number of people in the US and elsewhere whose workplaces are in caves or directly related to caves. In government and private-sector workplaces there are cave guides, biologists, geologists, archeologists, historians, academics, and law enforcement officers, to name just a few occupations working in and around caves. In particular, there are employees in the US National Park Service, Forest Service, and Bureau of Land Management whose jobs are directly related to caves and who may require specialized caving training to safely do their jobs (Goodbar, 2007). Unlike the recreational users of caves, this group has many more specific policies, rules, and regulations governing their time in caves. All US workplaces are required to remain in compliance with federal and state regulations, and one of the most important ways to accomplish this is through training (OSHA, 1998). There are many known hazards in caves that can pose risks, especially for workers who spend more time over the course of a year in caves than recreational visitors. In the park service, caves are treated more as natural resources than as workplaces. Historically, there has been little formal training concerning workplace hazards, even for work done along developed tour routes. Risk assessments (Goodbar, 2007) and risk estimates (Field, 2007) are used to ascertain true risk to humans from specific cave hazards. The outcomes of such risk analyses are used to prepare strategies, which will usually include training to prevent injuries, illnesses, and fatalities.

Each year in US caves, an average of 50 injuries and 3.3 fatalities are reported (Keeler, 2011, p. 7-9; Stella-Watts et al., 2012). Since 1986, there has been only one year, 2005, in which no fatalities were reported in US caves. In total, over the 22-year period from 1986 to 2008, 1,159 injuries and 75 fatalities in US caves have been recorded (Keeler, 2011). In UK caves, the raw numbers are lower. There were 22 reported incidents in 2010 and no fatalities, with an average of 28 incidents per year since 2006 (BCRC, 2010).

Caving is believed by many to be a dangerous activity. It is known to be associated with fatalities and severe injuries, including fractures, soft tissue injuries, and lacerations (Stella-Watts et al., 2012). Most injuries in caves are due to falls, which are also the primary cause of injuries for the broader population. Stella-Watts et al. reported a slightly different range of years from Keeler (2011), 1980 to 2008, in which there were 81 documented

\footnotetext{
*Corresponding Author: bird2@oakland.edu

${ }^{1}$ School of Health Sciences, Oakland University, Rochester, MI 48309

${ }^{2} \mathrm{CD}$-adapco, Northville, MI

${ }^{3}$ Jewel Cave National Monument, Custer, SD 57730
} 
fatalities and 1,159 injuries in US caves. Most of these fatalities and injuries occurred in undeveloped caves, where rescue and recovery can be extremely difficult. The total number of yearly visits to undeveloped caves is unknown. An estimated 2 million people visit US national park and monument caves each year (Hooker and Shalit, 2000), and the vast majority of these visits are to developed caves on park properties. Therefore, it is not possible to calculate an accurate rate of injury and fatality incidence for undeveloped caves in the US. Such a calculation has been attempted for caving incidents in the United Kingdom that occurred from 1988 to 1992, with the resulting value described as a Fatal Accident Rate (FAR) (Mohr, 2000). The UK caving FAR value of 157 was second highest among a number of UK sports, less than hang gliding and parasailing $(F A R=200)$ but significantly higher than rock climbing $($ FAR $=30$ to 60$)$, sailing $(F A R=20)$, and swimming $(F A R=12)$. This number seems quite high, as there are many years in the UK when no caving fatalities were reported. The FAR value presented here is based on a speculative visitation rate in UK caves, which if correct, shows that UK cavers are very well prepared when they enter caves. However, if the speculative visitation number is off, then a wide range of actual FAR values could be possible.

It is widely believed that training and education are useful for increasing awareness of hazards, with an end goal of training being the reduction or elimination of injuries, illnesses, and fatalities. Bird et al. (2003) provides a number of motivational approaches for enhancing safer behaviors, with arguably the most important one being behavioral reinforcement. Burke et al. (2006) reported that training involving behavioral modeling, practicing, and dialogue was effective for improving knowledge about hazards. This is further supported by the work of Robson et al. (2012), who also found evidence that training was effective for bringing about behavioral changes. However, the link to reduction of injuries, illnesses, and fatalities is not always clear. One reason for this is that trainers cannot easily compare the success of their training, as measured by tests or certifications, with the eventual incidence of problems (Goldenhar et al., 2001), because few injuries occur soon after training. The time lag between demonstration of learning outcomes, i.e., showing knowledge about hazards, and the occurrence of an injury make it difficult to track all of the factors that caused the undesired incident to occur.

The United States is one of just a few first world countries without a formal nation-wide caving-skills training program. One possible explanation for this may be that caving is perceived to be reasonably safe, and thus training is not needed. Another explanation could be that cavers are relatively few in numbers when compared to other sports, so there are simply too few cavers to support the infrastructure needed for a national caving training entity in the US. Still another explanation is that informal training - where skilled cavers personally train those with less skill to become safer cavers - currently meets the US need for development of safe-caving skills. This process is ongoing at many US national parks and monuments, such as Jewel Cave in South Dakota, where off trail rules and situational awareness are taught to trip leaders so that knowledge and skills can be informally passed on to trip participants. A fourth explanation is that regional differences in US caves require different caving techniques and equipment. It is also possible that cavers develop beliefs about caving that are based on their individual attitudes about centralized regulation. Further, the preferences of cavers regarding training will likely vary from region to region, and also according to their reason for entering a cave, experience level, training, and other beliefs and practices. Despite these possibilities, the actual reasons for the lack of formal caving-skills training in the US are unknown.

Safety has been a foundational tenet of formalized caving in the United States since the creation of the National Speleological Society as an outgrowth of the Speleological Society of the District of Columbia. William J. Stephenson penned two articles (Stephenson, 1940, 1941) focusing directly on caving safety. The first article, published in 1940, begins, "With the Speleological Society yet in its first year and with interest in caves growing apace, it seems appropriate that one of the first problems to be dealt with is that of safety." While the article contains discussions of caving approaches not commonly used today, it does make clear that skilled cavers of that time used techniques less risky than those of today. The article, however, does not discuss training. A similar article published one year later is more refined, specifically mentioning caving equipment selection and care, not rushing while moving through the cave, and being particularly cognizant of the two primary hazards in the cave, absence of light and slippery surfaces. Stephenson sets the stage for continued sharing of information on best practices in "methods, techniques, equipment, and exploring" by promising to print "any articles or notes any member sends in bearing on these points." Nevertheless, a review of early issues of the NSS Bulletin and NSS News reveals an absence of discussion of actual caving-skills training.

However, at a local level in the US, training did become a focus early in the history of active caving. One example is the effort within the VPI Cave Club in Blacksburg, Virginia, to formalize key caving skills through a series of Training Bulletins that were developed by Anne Whittemore and others for that and other clubs to use in their training efforts (VAR, 2000; personal communication with Robert Hoke, 2012). In a May 1951 President's Report, NSS President Charles E. Mohr wrote, "Orchids are due to the VPI Grotto for its splendid series of Training Bulletins.... Free copies are being mailed to other grottoes, and permission to copy part or all of them is given" (Mohr, 
1951). The list of bulletins was given later in the same 1951 issue of the NSS News. The VPI Cave Club has had constant training offerings, primarily for its student members, since the early 1950s and formally since 1961 . This may well be due to the establishment of best practices for safe caving described in the above bulletins. Establishment of and adherence to standard best practices is readily possible within a relatively small and cohesive organization like the VPI Cave Club. However, it is more of a challenge at the national level and would need to rely upon the structure of a larger organization and take into account regional preferences and caving conditions in order to be sustainable.

The US has seen attempts in the past to initiate formal, nationwide caving-skills training programs, including one that occurred in the 1950s and 1960s within the NSS. Beginning in 1958, the NSS Safety Committee (now the Safety and Techniques Committee) promoted a Qualified Caver and Qualified Leader training effort that included, among other things, demonstrating skills in knot-tying and belaying, carbide lamp operation and maintenance, and leading cave trips (Rane Curl, pers. comm.; Curl, 1958). A vote of the 1958 Congress of Grottos (NSS caving clubs) approved that the "National Safety Committee formalize a uniform-minimum safety-skill program" to be used by all in the NSS and to be implemented by individual grottos (Nicholas, 1958).

Training events were held from 1958 to 1960, and resulted in an increase in the numbers of cavers and cavetrip leaders who participated in the safety-skills program in the Midwest, California, and Texas. In 1960, the plan was simplified and distributed nationally by the NSS to its local chapters. The program was used by some grottos, but did not experience widespread adoption. Reasons for this are believed to include the program's reliance on volunteers and the opposition by some cavers to a national level program imposing uniform standards across the entire country (Rane Curl, pers. comm.).

Efforts to bring established caving skills to the broader membership of the NSS occurred on at least two subsequent occasions. In 1973, a vote was taken in the Congress of Grottos at the NSS Convention in Bloomington, Indiana, to determine the level of interest in certification (Devereaux, 1973). Positive interest in certification was expressed by a vote of 153 out of 159 . However, the effort does not appear to have gone much further, as no evidence was found indicating a caver certification program was ever initiated within the NSS. There was likely opposition to certification over the next few years, as indicated by the following quote in the 1976 NSS Caver Training Commission Report (Ediger, 1976), "The idea that the Caver Training Manual is a precursor to caver certification should be extirpated from the mind of anyone harboring such a notion!" Notably, the Caver Training Commission was renamed the Caver Training Committee in 1984. No additional references were found about this
Committee until 1996 when it was eliminated by an act of the NSS Board of Governors (NSS, 2012a).

Outside of the focus on caving skills and training for preventing injuries and fatalities, but still fully within the scope of caving training, is the National Cave Rescue Commission (NCRC). NCRC was established by an Act of the Board of Governors of the NSS in 1979 to, among other things, "prompt competence and cooperation among Society members, organizations, and related agencies in the field of cave rescue" (NSS, 2012a). The original wording has been replaced by the Charter of the National Cave Rescue Commission (NSS, 2003), which outlines the purposes, responsibilities, and management structure of the Commission, including training focused on cave rescue practices and procedures. Mirza (2003) summarizes the "mandates" in the charter as "to develop and teach [a] cave rescue curriculum," "to act as the "voice' of the NSS during cave rescues," and "to develop working relationships with various governmental agencies as needed to help coordinate in the event of a rescue."

In recent years, there have been multiple fatalities of individuals who were exploring caves for recreational purposes that invoked the mandates of the NCRC. In one case, two individuals died while attempting to climb a rope under a waterfall to retrieve a lost gear bag (Caulfield, 2011). In another, an individual crawled into a tight space from which he could not return (Farrell, 2009). Each of these deaths might have been avoided if the victims had taken formal caving-skills training. Since the US does not have such a program in place, the only option for reducing such fatalities would be through informal training in a caving club, which is sporadically offered throughout the US. Therefore, the continued presence of avoidable injuries and fatalities every year in US and UK caves is a valid reason for studying perceptions of caving skills training.

Mishaps in caves have significant emotional and psychological costs to the injured individual, families and friends, rescuers, and the communities; the actual costs in pain and suffering are immeasurable, and all injuries, illnesses, and fatalities in caves are to be avoided. However, with no intention of minimizing the significance of emotional impacts, it is possible to obtain an estimate of the economic loss from cave-related injuries and fatalities. Applying national average values (NSC, 2013), the average cost of an injury in 2011 US dollars is $\$ 8,300$ for nonworkplace-related injuries and the cost of an unexpected death outside of the workplace is $\$ 1.1$ million. Applied to recreational caving, the value of $\$ 8,300$ is likely too low, considering that injuries in caves require trained, equipped teams for extraction. A potential high-end value that could be used is around $\$ 54,000$, which represents the average cost of employer expenses for a person getting hurt at work. Using the NSC cost estimates and data in American Caving Accidents (Stella-Watts et al., 2012), the costs of injuries and fatalities in US caves over the twenty-threeyear period from 1986 through 2008 can be calculated to 
Table 1. Primary categories on questionnaire.

Category Questions in Category

Caving experience, training experience, membership in caving clubs or grottos, and primary caving regions

Impact, or lack thereof, of educating people about caving skills and techniques 9

Perceptions of the value, or lack thereof, of caving-skills training on reducing injuries and

fatalities in caves

Freeform comments

range from $\$ 106$ million to $\$ 147$ million, using equivalent 2011 US dollars.

\section{Materials And Methods}

An online, anonymous questionnaire was used for gathering information about the perceived value of formal caving-skills training. The Oakland University Institutional Review Board (IRB) for protection of human research participants reviewed and approved the questionnaire, participant recruiting approaches, and the associated consent forms.

The questionnaire included twenty-five items for gathering information about the perceived value of formal caving-skills training. Formal caving-skills training in this research is used to mean caving classes that are designed to teach a wide variety of people, that are scheduled, and that incorporate some measure of successful instruction. Four primary categories of information were requested from participants (Table 1). The first group of questions collected information on caving experience, membership in caving clubs or grottos, and primary caving region. The second group of questions collected information on the impact, or lack thereof, of educating people about caving skills and techniques. The third group investigated personal beliefs regarding the benefits or detriments of caving-skills training. The fourth group was intended to gauge perceptions of the value, or lack thereof, of caving-skills training. The fourth group was a single opportunity for respondents to write comments about caving training in their own words. The second and third categories contained questions intended to assess beliefs concerning past experience, as well as potential future outcomes. Responses from the online questionnaires were obtained anonymously and have no associated personal identifiers.

Table 2. Experience level categories for data analysis.

\begin{tabular}{lc}
\hline Coded Levels & Years of Experience \\
\hline 1 & $0-3$ \\
2 & $3-5$ \\
3 & $5-10$ \\
4 & $10+$ \\
\hline
\end{tabular}

Anyone who wished to complete the online surveys could do so. Responses were analyzed for those who visited caves and actually go caving.

Analyses of participant responses included determining the frequency of responses to particular questions and then reporting the outcomes. T-tests for independent means were used to determine whether differences of means were significant. Resulting values from t-tests include the $t$ statistic, which is related to the size difference between the means of two samples, and $p$ value, which is a probability indication; if $p<0.05$, there is a 95 percent probability that the difference is real for the populations being studied. One-way ANOVA were used for comparisons of means of more than two groups. This is a statistical procedure using $F$-ratio to determine whether the group means differ (Field, 2009). Filtering by categories was conducted to create blocks of participant feedback for comparison within question-response groups. Primary categories include experience, training level, and preferred caving region. Responses were categorized according to years of caving experience (Table 2). Within these categories, further subdivisions were made for type of training including formal, informal, and rescue.

\section{Results}

Participants completed 135 questionnaires on perceptions of caving-skills training. Data were analyzed by experience, the kind of training the responder had, and preferred caving region. Respondents indicating the US and UK as their primary country for caving made up 98\% of all responses, and thus, regional analysis is focused on these groups. Of these, 98 responses were from North America; 35 were from the UK and Ireland. Of all responses, 73 percent reported the US being their primary country for caving, 25 percent reported caving in UK, and the remainder indicated Belize, Canada, Ireland, Slovenia, and Spain. Among responses from cavers indicating the US as their primary country for caving, 24\% listed the Southeast as most preferred region, 23\% the Virginias, 10\% Texas, and 9\% the Ohio Valley (Table 3). UK cavers listed Derbyshire and Yorkshire (63\%) and Wales (22\%), followed by Devon and Mendip (15\%), as their primary caving regions (Fig. 1). There were one or two responses 
Table 3. US response and residence percentages by region.

\begin{tabular}{lcc}
\hline Region & $\begin{array}{c}\text { Percentage of NSS } \\
\text { Members Residing } \\
\text { in the Region }\end{array}$ & $\begin{array}{c}\text { Percentage of } \\
\text { Cavers } \\
\text { in Residing } \\
\text { ine Region }\end{array}$ \\
\hline Northeast & 7.3 & 5.0 \\
Mid Atlantic & 5.2 & 9.9 \\
Virginias & 23.0 & 9.2 \\
Ohio Valley & 9.4 & 10.4 \\
Southeast & 24.0 & 25.3 \\
Midwest & 4.2 & 11.3 \\
Rockies & 6.2 & 6.8 \\
Texas & 10.4 & 4.5 \\
Southwest & 5.2 & 4.4 \\
Western & 5.2 & 9.0 \\
\hline
\end{tabular}

${ }^{a}$ NSS, 2012b, p. 56.

each from Belize; Counties Clare and Fermanagh, Ireland; Eastern and Southern Europe; Julian Alps, Slovenia; Matienzo, Spain; Manitoba, Canada; and Puerto Rico.

The participants tended to have quite a bit of experience: 60 percent of respondents had at least ten years of caving experience; 6.6 percent of all respondents reported having 0 to 2 years experience; 16 percent reported having 2 to 5 years experience; 12 percent had 5 to 10 years; 28.5 percent reported 10 to 20 years of experience and 36.5 percent reported having more than 20 years of caving experience. Generally, experienced cavers appeared to be more likely to respond to the survey than those with less experience. Of note, the most prevalent caving regions in the US (Southeast) and the UK (Yorkshire and Derbyshire) have respondents with the least amount of experience, although the averages are 10 and 12 years respectively (Figure 2). The high population densities and the many caves in these areas might explain this.

Overall, 95 percent of respondents reported having had some kind of training, formal, informal, or rescue. Among this group, informal training is most prevalent at just above 50 percent. Those with rescue training are fewer than 10 percent of the group, while those with formal training make up the remainder. As shown in Figure 3, informal training is more common in the UK, whereas formal training is more common in the preferred caving regions of the US. Rescue training, however, is common in the Western and Mid-Atlantic regions as well as the Virginias and Ohio Valley. Informal training is more common in the Southwest, Midwest, and Northeast regions.

Respondents to the questionnaire were categorized according to years of experience from 0 to 3,3 to 5,5 to 10, and greater than 10 (see Table 2). Analysis of the data indicates that having more experience does not necessarily

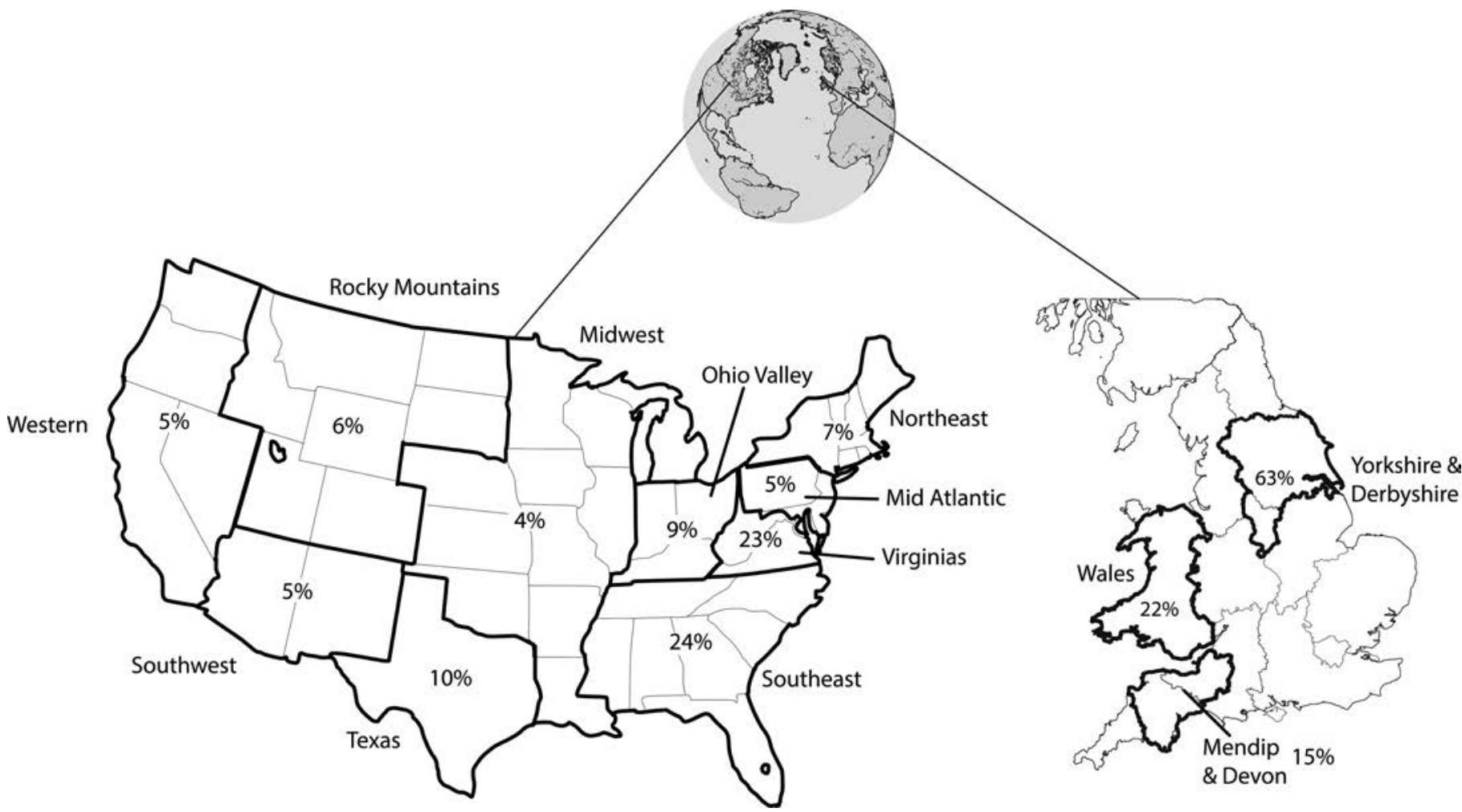

Figure 1. Percentages of preferred caving regions among US and UK respondents. Values in this figure are rounded, and percentages are calculated separately for each country. Table 3 contains US respondents' regional caving preferences compared to their residences. 


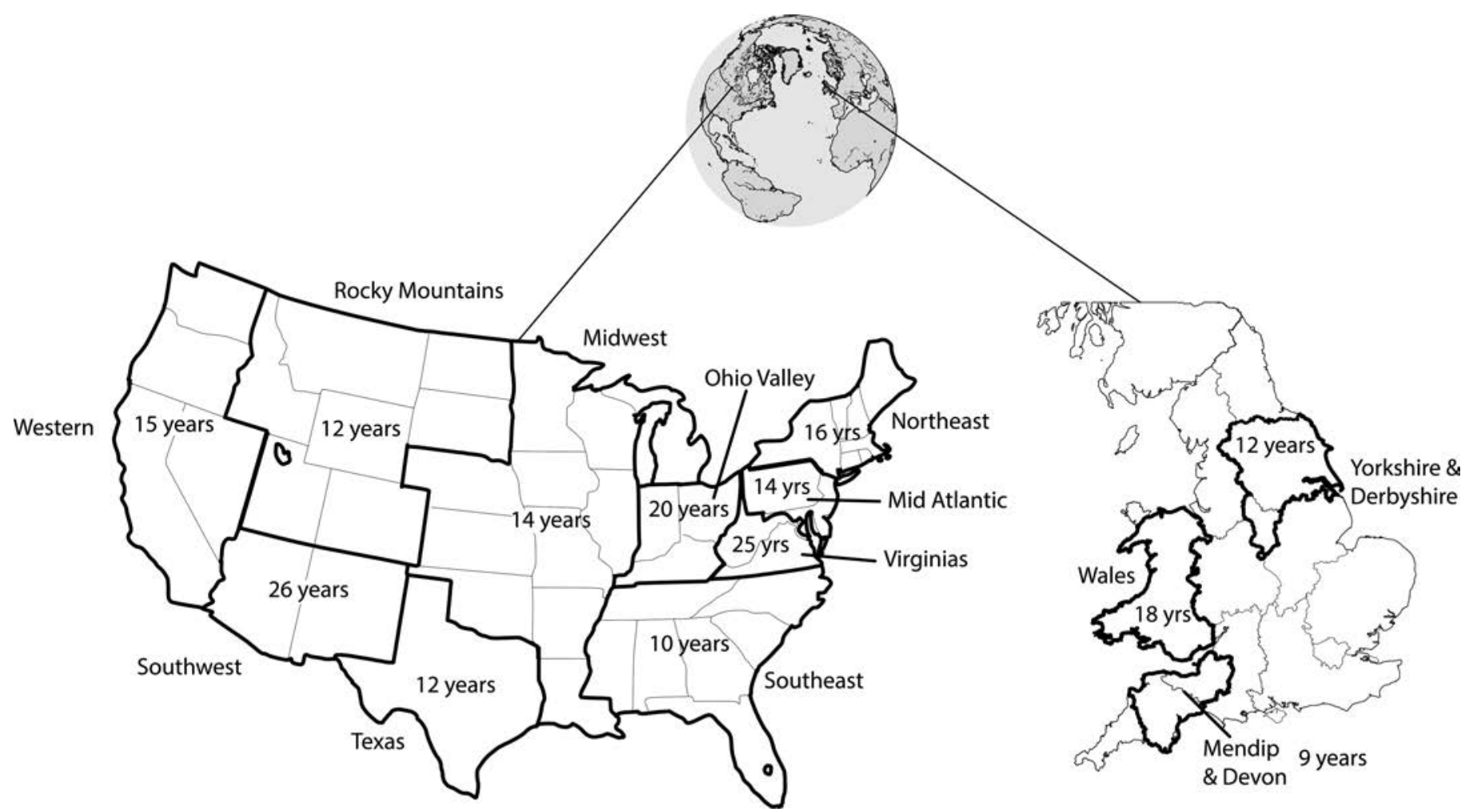

Figure 2. Respondents' mean years of experience by preferred caving region.

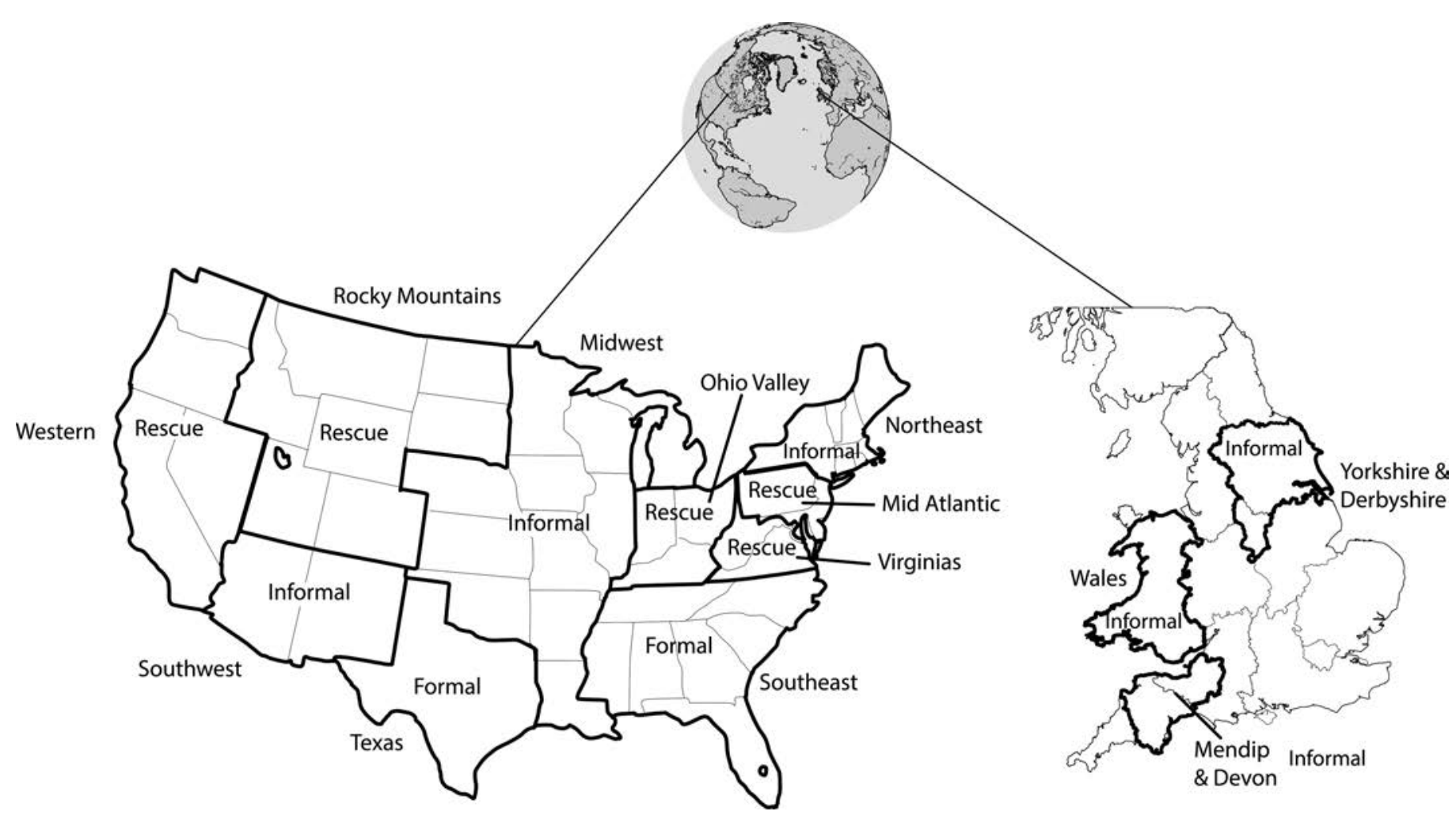

Figure 3. Most prevalent type of training (informal, formal, or rescue) by region as reported by respondents in the US and UK. 
Table 4. Survey question responses from the USA and from the UK by country and by region.

\begin{tabular}{lccc}
\hline & \multicolumn{3}{c}{ Percent Agreement } \\
\cline { 2 - 4 } Country/Region & $\begin{array}{c}\text { Among Respondents with } \\
\text { Formal Training (percent) }\end{array}$ & $\begin{array}{c}\text { Among Respondents with } \\
\text { Informal Training (percent) }\end{array}$ & $\begin{array}{c}\text { Among All Respondents } \\
\text { (percent) }\end{array}$ \\
\hline United States & 89 & 76 & 81 \\
Northeast & & & 67 \\
Mid Atlantic & & 75 \\
Virginias & & & 81 \\
Ohio Valley & & & 100 \\
Southeast & & 79 \\
Midwest & & 67 \\
Texas & & 67 & 78 \\
Rocky Mountains & & & 60 \\
Southwest & & & 100 \\
Western & & & 70 \\
United Kingdom & & 67 \\
Devon \& Mendip & & & 60 \\
Derbyshire \& Yorkshire & & & 100 \\
Wales & & & 60 \\
\hline
\end{tabular}

mean cavers are more likely to have had formal cavingskills training: $F(3,124)=0.26, p=0.86$. However, statistical significance is obtained when looking at those with formal rescue training at an experience level greater than ten years: $F(3,126)=6.25, p<0.001$. Thus, respondents who have had cave rescue training are statistically more likely to be more experienced, and, vice versa, successful veteran cavers might accumulate more "experiential training equivalents" than would be provided through formal training. Subdividing by country, 53 percent of US respondents and 33 percent in UK report having had formal caving-skills training, not including cave rescue. When cave rescue is added, 61 percent of US respondents report having had formal caving-skills training, including rescue. When adding cave rescue, the percentage does not change among UK respondents.

The majority of respondents in the US (81\%) agree that individuals entering caves without knowledge or skill are more likely to be injured or killed (see Table 4 for breakdown of responses by region). Respondents who have received formal training agree more $(89 \%)$ than respondents who have received informal training (76\%). However, only 70 percent of respondents in the UK agree with this statement, and there are no differences between those who have received formal and informal training.

\section{Perceptions of Training}

Combining all variables (region, experience, and types of training received by respondents), shows that 93 percent believe that the knowledge and skills they have acquired helps them safely explore caves. When the question was phrased "without training I would be injured," fewer than
70 percent report that training was purely responsible for them being safe cavers. This raises the question of whether caving safely is mostly the result of experience or training or more likely a combination of both. In this category, 87 percent believe that improving and increasing their knowledge and skills will have a further positive effect on how safely they move about in caves. Differences do occur, however, for confidence in caving skills obtained from training. While nearly all respondents believe training made them more confident cavers (84\%), those who obtained knowledge and skill through formal caving-skills training agree more strongly than those who obtained training by other means, $t(124)=-2.67, p<0.001)$. However, this result is not consistent for those who have had formal cave rescue training, $t(119)=0.4576$ (i.e., cave rescue training does not make them more confident in their caving skills abilities). Formal cave rescue training programs offered in the US usually assume trainees will have some existing caving skills, because the purpose of the training is rescue in the cave environment, not caving skills development. Of note, research participants were not asked if formal cave rescue training made them more confident rescuers, although one would surmise it to be the case.

These results suggest training is critical, but it is interesting to note that 44 percent of respondents in the US report did not know where they can get caving-skills training. On the other hand, respondents from the UK overwhelming report being aware of caving skills training opportunities $(83 \%), t(121)=4.14, p<0.001$, but more people in the US would attend training if the courses were tailored to fit their needs than cavers in the UK, $t(120)=2.25, p<0.05$.

Confidence in caving is, of course, very important. However, actual outcomes can reveal the full impact of 
using training to prepare for cave exploration. Respondents report that formal training $(t(124)=2.20, p<0.05)$ and formal rescue training $(t(126)=2.30, p<0.01)$ have helped save their own or others lives while exploring caves. Furthermore, regardless of the type of training received, respondents report that without the knowledge and skill obtained from training, they believe there would be a high probability they could be injured or killed when they explore highly hazardous caves $(69 \%)$. It is likely that an experienced caver would understand what activities and conditions are beyond normal comfort level and take steps to prepare for or avoid such situations.

Regarding potential future impact of training, respondents believe that improving knowledge and skill of caving will allow them to more safely explore caves, $t(123)=2.25$, $p<0.05$. Furthermore, 62 percent of respondents believe there is a need for new and improved training programs. This prevalence, however, decreases slightly among cavers who have more than ten years of caving experience, where only 54 percent indicate a need. This may be because experienced cavers are more likely to turn to their more experienced peers, rather than put their trust in a training program.

\section{Discussion}

It might be expected that the occurrences of injuries, illnesses, and fatalities in caves would influence people's beliefs that there should be additional training beyond what is already being offered. The majority of all respondents in this study agree. However, among those who report having had caving-skills-related training, only those with rescue training come close to statistical significance in associating the presence of accidents and incidents with a need for more training. This is so because there is emphasis in cave rescue training on creating achievable outcomes, i.e., successfully rescuing a simulated injured caver, in order to enhance learning of the key objectives of the course. This likely creates a connection between the training environment (simulated cave rescues involving injuries, illnesses, and/or fatalities) and the successful demonstration of desired learning outcomes. Subsequently, this means that cave rescue trainees value training that positively addresses events associated with caving-related mishaps. The purposes of general cavingskills-related training are to successfully and confidently negotiate the cave environment, not to deal with injuries, illnesses, or fatalities. This further explains why there is no association observed in the data.

In the US, formal caving-skills training is more prevalent. However, most respondents in the UK report having had informal training. Participants' qualitative comments provide some reasons for this. In the UK there is very little caver training for the new novice caver other than SRT. Nearly all the training is done at the club level and mainly through experience with novice trips being arranged.
Additional comments from respondents indicate that many are members of caving clubs affiliated with UK universities. In a study on culture in the United Kingdom, it has been suggested that there are rebellious and conscientious "post-materialistic" concerns among more educated sections of the UK population, whereas less educated and older portions of the population have more materialistic concerns (Majima and Savage, 2007). That is, they are less likely to comply with the constraints of structured organizations and prefer sports and endeavors that allow them to behave more freely. This ideology, assuming it is present within the university caving clubs, may provide some sort of explanation for the much lower prevalence of formal training in the UK, even though it is more readily available to UK cavers.

A number of respondents, both in the US and UK, express preference for informal caving-skills training, particularly because they are able to work directly with those who have more experience and knowledge, much like an apprentice-mentor teaching and learning model. Adultstyle learning should focus on "discovery learning" where the individual is motivated to learn because of his desire to understand what he is learning (Knowles et al., 1998). Hands-on training is not necessarily incorporated into formal training; many respondents to the qualitative portion of this study suggested that caving training is preferred when it involves hands-on experiences in an informal setting. It has been suggested that new information is only imputed when there is an opportunity to reflect on experience consistent with the concept of "hands-on" learning or learning from practice (Bleakley, 2000), which again lends itself very well to the informal, apprenticementor learning model. We find it safest to incorporate an enthusiastic new caver into increasingly more difficult caving trips, and educate them on-site, as needed. A limited amount of vertical training and practice can be done above ground and prior to a trip, but nothing beats actual in-cave experience, especially when it comes to rigging ropes.

Informal training is clearly desirable, popular, and apparently effective. However, respondents report that formal caving-skills training makes them more confident cavers than other forms of training. Research shows that confidence is associated with higher performance (Compte and Postlewaite, 2004). However, qualitative comments on the questionnaires provide cautions about becoming overconfident through formal caving-skills training. "Formal courses can teach skills and techniques - what they can not provide is judgment and experience."

Formal caving-skills training has the benefit of being designed with clear learning objectives and measures of learning outcomes. Informal training is likely more comfortable and tailored to the individual trainees' learning paces and specific needs. Furthermore, because informal training is similar to apprentice-mentor models, it also provides the benefit of allowing trainees to reflect and synthesize what they've learned and practiced. It may be 
possible to blend the benefits of these two approaches, wherein learning objectives and measures of learning outcomes are included within the apprentice-mentor model.

\section{CONCLUSIONS}

The cavers who participated in this study are experienced and trained, most through informal caving-skills training. Regionally, there are differences in experience level, training level, and perceptions among respondents. Of note, the two most popular caving areas in the US and UK, namely the southeast US and Yorkshire in the UK, have the least experienced responders, although average experience in each of these locations is 10 and 12 years, respectively. Respondents from a number of regional locations in the US have formal, cave-rescue-trained individuals as the highest percentage. In the UK, however, all caving regions have informally trained cavers as the highest percentages. Both formal and informal caving skills training have benefits. A blend of the two is likely the best approach for optimizing learning outcomes in caving-skills training.

\section{AcKNOWLEDGEMENTS}

The authors would like to thank Christopher Binding, Rachel Bosch, Jansen Cardy, Rane Curl, Amy Hinkle, Art Palmer, and Wm Shrewsbury for assistance in finding study participants, for contributing their expertise of caving cultures in the US and the UK, and reviewing drafts of this paper.

\section{REFERENCES}

Bird, F.E., Germain, G.L., and Clark, M.D., 2003, Practical Loss Control Leadership, Third Edition, Det Norske Veritas, p. 70-77.

Bleakley, A., 2000, Writing with invisible ink: Narrative, confessionalism and reflective practice: Reflective Practice: International and Multidisciplinary Perspectives, v. 1, no. 1, p. 11-24. doi:10.1080/713693130.

British Caving Association (BCA), 2011, Membership Administrator's Report: Draft Minutes of BCA Annual General Meeting held on Saturday 11th June 2011 at Alvechurch Church Hall, Alvechurch. http:// british-caving.org.uk/admin/AGM\%20Minutes\%202011.pdf [accessed November 7, 2012].

British Cave Rescue Council (BCRC), 2010, Incident Report for Period $1^{\text {st }}$ January $2010-31^{\text {st }}$ December 2010. http://www.caverescue.org.uk/ IREPPDF/2010IRep[A].pdf [accessed November 7, 2012].

Burke, M.J., Sarpy, S.A., Smith-Crowe, K., Chan-Serafin, S., Salvador, R.O., and Islam, G., 2006, Relative effectiveness of worker safety and health training methods: American Journal of Public Health, v. 96, no. 2, p. 315-324. doi:10.2105/AJPH.2004.059840.

Caulfield, P., 2011, 2 University of Florida students die after getting trapped in cave during trip in Georgia mountains. http://www. nydailynews.com/news/national/article-1.133657 [accessed November 7, 2012].

Compte, O., and Postlewaite, A., 2004, Confidence-enhanced performance: The American Economic Review, v. 94, no. 5, p. 1536-1557. doi: $10.1257 / 0002828043052204$.

Curl, R., 1958, Minimum safety skills: NSS News, v. 16, no. 6, 58 p.

Devereaux, R., 1973, An appeal: NSS News, v. 31, no. 12, 216 p.
Ediger, G., 1976, Caver training committee reports: NSS News, v. 34, no. 2,28 p.

Farrell, M.B., 2009, Nutty Putty Cave to be closed for good after trapped caver's death: The Christian Science Monitor. http://www.csmonitor. com/USA/2009/1128/p02s07-usgn.html [accessed November 7, 2012].

Field, A., 2009, Discovering Statistics Using SPSS, Third Edition, London, SAGE Publications, $856 \mathrm{p}$.

Field, M.S., 2007, Risks to cavers and cave workers from exposures to low-level ionizing $\alpha$ radiation from ${ }^{222} \mathrm{Rn}$ decay in caves: Journal of Cave and Karst Studies, v. 69, no. 1, p. 207-228.

Goldenhar, L.M., Moran, S.K., and Colligan, M., 2001, Health and safety training in a sample of open-shop construction companies: Journal of Safety Research, v. 32, p. 237-252. doi:10.1016/S0022-4375(01)00045-7.

Goodbar, J., 2007, Cave Safety Standards: Bureau of Land Management, Washington Office. http://www.blm.gov/pgdata/etc/medialib/blm/wo/ Information_Resources_Management/policy/im_attachments/2008. Par.6397.File.dat/IM2008-105_att1.pdf. [accessed November 7, 2012].

Hooker, K., and Shalit, M., 2000, Subterranean medicine: an inquiry into underground medical treatment protocols in cave rescue situations in national parks in the United States: Wilderness and Environmental Medicine, v. 11, p. 17-20. doi:10.1580/1080-6032(2000)011[0017:SMAIIU] 2.3.CO;2.

Keeler, R., ed., 2011, American Caving Accidents 2009-2010: NSS News, v. 69 , no. 10 , part 2.

Knowles, M.S., Holton, E.F. III., and Swanson, R.A., 1998, The Adult Learner, Fifth Edition, Oxford, Butterworth-Heinemann.

Majima, S., and Savage, M., 2007, Have there been culture shifts in Britain? A critical encounter with Ronald Inglehart: Cultural Sociology, v. 1, no. 3, p. 293-315. doi:10.1177/1749975507082050

Mirza, A., 2003, Cave rescue training isn't just for rescue geeks: NSS News, v. 61 , no. 12,353 p.

Mohr, C.E., 1951, President's annual report: NSS News, v. 9, no. 6, 5 p.

Mohr, P., 2000, Gauging the risk: Descent no. 153 (April/May), p. 20-23.

National Safety Council (NSC), 2013, Estimating the Costs of Unintentional Injuries, http://www.nsc.org/news_resources/injury_and_death_ statistics/Pages/EstimatingtheCostsofUnintentionalInjuries.aspx [accessed July 15, 2013].

National Speleological Society (NSS), 2003, Charter of the National Cave Rescue Commission: NSS Board of Governors Manual, Acts of the Board Appendix S, amended May 15, 2003. https://secure.caves.org/ nss-business/bog/Append-S.pdf [accessed July 15, 2013].

National Speleological Society (NSS), 2012a, Text of Repealed and Obsolete Acts: NSS Board of Governors Manual, Section 7, https:// secure.caves.org/nss-business/bog/Repealed_and_Obsolete_Acts.pdf [accessed February 2012].

National Speleological Society (NSS), 2012b, 2012 Members Manual, (NSS News, v. 69, no. 4, part 2), 160 p.

Nicholas, G., 1958, President's column: NSS News, v. 16, no. 6, p. 51-52.

Occupational Safety and Health Administration (OSHA), 1998, Training Requirements in OSHA Standards and Training Guidelines, Revised: US Department of Labor, Occupational Safety and Health Administration. < https://www.osha.gov/publications/osha2254.pdf $>$ [accessed March 25, 2012].

Robson, L.S., Stephenson, C.M., Schulte, P.A., Amick, B.C. III., Irvin, E.L., Eggerth, D.E., Chang, S., Bielecky, A.R., Wang, A.M., Heidotting, T.L., Peters, R.H., Clark, J.A., Cullen, K., Rotunda, C.J., and Grubb, P.L., 2012, A systematic review of the effectiveness of occupational health and safety training: Scandinavian Journal of Work, Environment and Health, v. 38, no. 3, p. 193-208. doi:10.5271/ sjweh.3259.

Stella-Watts, A.C., Holstege, C.P., Lee, J.C., and Charlton, N.P., 2012, The epidemiology of caving injuries in the United States: Wilderness and Environmental Medicine, v. 23, p. 215-222. doi:10.1016/ j.wem.2012.03.004.

Stephenson, W.J., 1940, Caving safety, Bulletin of the Speleological Society of the District of Columbia, p. [25-29].

Stephenson, W.J., 1941, Advanced cave safety: Bulletin of the National Speleological Society, v. 2, p. 1-3.

Virginia Region of the National Speleological Society (VAR), 2000, VPI: VAR Grotto History, June, 5, 2000. http://www.varegion.org/var/ theVar/history71/pg209VPI2.html [accessed March 25, 2012]. 